\title{
Cardiovascular and respiratory alterations in dogs during cervical myelography using ioversol
}

\author{
[Alterações cardiovasculares e respiratórias durante a mielografia cervical \\ com ioversol em cães] \\ S.R.A. Melo e Silva ${ }^{1}$, E.A. Tudury ${ }^{2}$, V.B. Albuquerque ${ }^{3}$, F.P. Araújo ${ }^{4}$, T.F.B. Souza ${ }^{5}$, \\ P. I. Nóbrega Neto ${ }^{1}$, M.A. Bonelli ${ }^{2}$ \\ ${ }^{1}$ Hospital Veterinário - Universidade Federal de Campina Grande - Patos, PB \\ ${ }^{2}$ Universidade Federal Rural de Pernambuco - Recife, PE \\ ${ }^{3}$ Universidade Estadual Paulista - Campus de Botucatu, SP \\ ${ }^{4}$ Médico veterinário autônomo \\ ${ }^{5}$ Universidade Estadual Paulista - Campus de Araçatuba, SP
}

\begin{abstract}
Subarachnoid infusion of most contrast mediums and the steps involved in performing a cervical myelography have adverse affects that can discourage its use in the radiographic diagnosis of spinal cord diseases. Thus, the cardiovascular and respiratory alterations associated with neck flexion, subarachnoid puncture, and cerebrospinal fluid drainage during subarachnoid infusion of ioversol $(320 \mathrm{mgI} / \mathrm{mL})$ in dogs under general anesthesia using isoflurane were evaluated. The dogs received subarachnoid infusion of autologous cerebrospinal fluid kept at $38^{\circ} \mathrm{C}$ - control group (GC); ioversol $0.3 \mathrm{~mL} / \mathrm{kg}$ at $25^{\circ} \mathrm{C}$ (GI25) and ioversol $0.3 \mathrm{~mL} / \mathrm{kg}$ heated to $38^{\circ} \mathrm{C}$ (GI38). Each dog had its heart rate (HR), systolic arterial pressure (SAP), diastolic arterial pressure (DAP), respiratory rate (RR), oxyhemoglobin saturation $\left(\mathrm{SaO}_{2}\right)$ and electrocardiography readings (PR and QT intervals) recorded. Group comparisons showed no statistical difference regarding neck positioning, subarachnoid puncture, and subarachnoid infusion of contrast medium on $\mathrm{HR}$, RR and $\mathrm{SaO}_{2}$, cardiac rhythm or conduction. However, isoflurane significantly increased PR and QT intervals. Based on these findings, it is concluded that the steps involved in cervical myelography and the use of ioversol $320 \mathrm{mgI} / \mathrm{mL}$ at $0.3 \mathrm{~mL} / \mathrm{kg}\left(25^{\circ} \mathrm{C}\right.$ and $\left.38^{\circ} \mathrm{C}\right)$ during cervical myelography did not result in relevant cardiovascular and respiratory alterations, except for an elevation in arterial pressure after injection of ioversol.
\end{abstract}

Keywords: dog, myelography, optiray 320, cardiac arrhythmia, arterial pressure

\section{RESUMO}

Os efeitos adversos provocados pela infusão subaracnoidea de meios de contraste e da mielografia cervical podem desencorajar sua aplicação como alternativa para o diagnóstico radiológico de doenças da medula espinhal. Assim, avaliaram-se os efeitos cardiovascular e respiratório dos procedimentos técnicos necessários à mielografia cervical e da infusão subaracnoidea do ioversol - 320mgI/ $\mathrm{mL}$ - em cães anestesiados com isofluorano. Foi realizada infusão do líquido cefalorraquidiano autólogo mantido a $38^{\circ} \mathrm{C}$ - grupo-controle $(G C)$; infusão do ioversol 0,3mL/kg a $25^{\circ} \mathrm{C}$ (GI25); e infusão do ioversol $0,3 \mathrm{~mL} / \mathrm{kg}$ aquecido a $38^{\circ} \mathrm{C}(\mathrm{GI} 38)$. Estudaram-se: pressões arteriais sistólica $(P A S)$ e diastólica $(P A D)$, frequências cardíaca $(F C)$ e respiratória $(F R)$, saturação de oxi-hemoglobina $\left(\mathrm{SaO}_{2}\right)$ e medidas eletrocardiográficas (intervalos $P R$ e $Q T$ ). Não houve influência significativa do posicionamento, da punção ou da infusão subaracnoidea do ioversol sobre FC, FR, $\mathrm{SaO}_{2}$, ritmo e condução cardíaca, entretanto o isofluorano aumentou significativamente os intervalos $P R$ e QT. Concluiu-se que a mielografia cervical com ioversol 320 mgI $/ \mathrm{mL}$, nas temperaturas de $25^{\circ} \mathrm{C}$ e $38^{\circ} \mathrm{C}$ e na dose de $0,3 \mathrm{~mL} / \mathrm{kg}$, não causa arritmias cardiacas nem alterações cardiovasculares e respiratórias relevantes, exceto elevação da pressão arterial após a injeção do contraste.

Palavras-chave: canino, mielografia, optiray 320, arritmia cardíaca, pressão arterial

Recebido em 13 de novembro de 2011

Aceito em 29 de novembro de 2012

E-mail: silva_sergioricardo@yahoo.com.br 


\section{INTRODUCTION}

Over the years, commercially available contrast mediums have evolved in order to offer fewer risks to the patient. Even so, myelography is not an innocuous procedure, and it may cause adverse reactions in humans, such as headaches, nausea, vomiting, and even worsening of preexistent neurologic symptoms (Gelmers, 1979). There have also been reports of tachycardia (Widmer and Blevins, 1991) and bradycardia (Lewis and Hosgood, 1992) of undetermined origin occurring in dogs that underwent myelography via cerebellomedullary cistern injection of contrast medium, as well as seizures (mainly during recovery from anesthesia (Roberts and Selcer, 1993). More severe symptoms observed were episodes of ventricular arrhythmias and low arterial pressure in humans (Lehmann et al., 1987; Benamor et al., 1989; Hirshfeld et al., 1989) and dogs (Ralston et al., 1989; Wheeler and Sharp, 1999).

Research in humans has shown that trauma to the cervical spine involving the caudal brainstem can cause arterial hypotension and cardiac arrhythmias (Greenhoot and Mauck, 1972; Lehmann et al., 1987). This can be explained by the proximity of the medullary region of the caudal brainstem, where vasomotor and respiratory centers are located, thus susceptible to parasympathetic stimulation (Evans et al., 1980). In dogs, respiratory arrest and death have been observed following surgical decompression of the cervical spine (Clark, 1986). Cardiac arrhythmias, arterial hypotension, bradycardia and sinus arrest can also occur in dogs with cardiovascular disease due to vagal stimulation following endotracheal intubation (Paiva et al., 2002).

Continuous monitoring of patients with spinal cord injuries should include electrocardiography, pulse oximetry and arterial pressure monitoring, which allow recognition and treatment of severe cardiac arrhythmias and alterations in arterial pressure, when necessary (Evans et al., 1980; Wheeler and Sharp, 1999; Nunes, 2002).

In Canada and Europe, ioversol $(240 \mathrm{mgI} / \mathrm{mL})$ is administered subarachnoidally for conventional myelography and computed tomography of the spinal column in humans (Wible et al., 1995; Drug..., 2002) and dogs (Tudury et al., 1997).
Several studies have confirmed its high diagnostic quality (McClennan and Bettmann, 1989) and low neurotoxicity (Ralston et al., 1989; Doucet and Idée, 1992; Wible et al., 1995). Looking at alterations in synaptic transmission within the central nervous system (CNS), researchers have found satisfactory results that indicate that ioversol has low epileptogenic activity (Wible et al., 1995; La Noce et al., 1996; Frigeni et al., 2002). Ioversol quickly diffuses from the cisterna magna into the adjacent brain tissue, where traces can remain up to 24 hours after infusion (Jacobsen, 1992; Wible et al., 1995).

Dogs undergoing myelography are subject to side effects such as tremors, fasciculations, limb withdrawal, tachycardia and apnea, as well as alterations in cerebrospinal fluid (CSF) four days after infusion (Tudury et al., 1997). Despite the side effects seen with ioversol, patient tolerance is considered high in human medicine, and its use is indicated in high risk, elderly, diabetic, heart and kidney disease patients (Benamor et al., 1989; McClennan and Bettmann, 1989).

The objective of this study was to evaluate the cardiovascular and respiratory effects caused by the steps involved in cervical myelography (neck flexion, subarachnoid puncture, collection of CSF) and during the subarachnoid infusion of ioversol $(320 \mathrm{mgI} / \mathrm{mL})$ in dogs under general anesthesia using isoflurane.

\section{MATERIAL AND METHODS}

Following authorization from the Ethics Committee of the Departmento de Medicina Veterinária da Universidade Federal Rural de Pernambuco (n. 154/2002), 60 apparently healthy mongrel bitches were obtained from the Center for Zoonotic Diseases in Recife - PE. The dogs aged between 1 and 2 years, and weighed between 8 and $20 \mathrm{~kg}(12.98 \pm 2.9)$. They were divided in three groups composed of 20 dogs each: control group (GC); GI25 group and GI38 group.

All dogs underwent physical and neurological exams prior to the start of the experiment, including electrocardiography (ECG) and noninvasive measurement of arterial blood pressure. They were kept in individual stalls with food and water for seven days before the beginning of the 
experiment. At the end of the experiment, the dogs were either adopted or returned to the Center for Zoonotic Diseases.

All dogs were anesthetized using the same anesthetic protocol: diazepam (Compaz, Cristália, São Paulo, SP) at $0.5 \mathrm{mg} / \mathrm{kg}$ and tramadol hydrochloride (Tramadon, Cristália, São Paulo, SP) at $2 \mathrm{mg} / \mathrm{kg}$, mixed in the same syringe and administered intramuscularly. After 15 minutes, the lateral saphenous vein was catheterized and Lactated Ringer's solution (heated to $38^{\circ} \mathrm{C}$ ) administered intravenously at $10 \mathrm{~mL} / \mathrm{kg} / \mathrm{h}$. Anesthesia was induced with a single bolus intravenous injection of etomidate $2 \mathrm{mg} / \mathrm{kg}$ (Etomidato, Cristália, São Paulo, SP). After endotracheal intubation, the dogs received $100 \%$ Oxygen $(15 \mathrm{~mL} / \mathrm{kg} / \mathrm{minute})$ and anesthesia was maintained with isoflurane (Isoforine, Cristália, São Paulo, SP) via a semi-closed breathing circuit during 30 minutes to ensure a surgical plane of anesthesia, which was maintained throughout the experiment.

Dogs from the control group had CSF collected and reinfused into the cerebellomedullary cistern at $38^{\circ} \mathrm{C}$. The second group (GI25) received an infusion of the contrast medium ioversol, $0.3 \mathrm{~mL} / \mathrm{kg}$ at $320 \mathrm{mgI} / \mathrm{mL}$ (Optiray 320 Mallinckrodt Chemical Ltd., Chesterfield, UK) at a temperature of $25^{\circ} \mathrm{C}$, also into the cerebellomedullary cistern. The third group (GI38) underwent the same procedure as described for GI25, except that the ioversol was heated to $38^{\circ} \mathrm{C}$. The rate of subarachnoid infusion was $1 \mathrm{~mL} / 30 \mathrm{~s}$ in all groups.

Each dog was continuously monitored during every step of the myelography procedure using computer-assisted electrocardiography (TEB C10 - Tecnologia Eletrônica Brasileira Ltda, São Paulo - SP - Brazil) and multi-parametric monitor (DX 2010 LCD - DIXTAL Biomédica, São Paulo, SP - Brazil). Neurological exams were repeated after recovery from anesthesia.

The steps involved in performing a cervical myelography were divided into moments and analyzed separately: basal moment, at 30 minutes after induction of anesthesia with isoflurane (M0); ventral flexion of the neck (MFlex); concomitant spinal tap and CSF collection (MPuDr); infusion of CSF or ioversol (MInf); and five minutes after infusion of CSF or contrast medium $(\mathrm{MInf}+5)$. In each moment (M0, Mflex, MpuDr, MInf and MInf+5), heart rate (HR), respiratory rate (RR), systolic (SAP) and diastolic (DAP) pressures, oxyhemoglobin saturation $\left(\mathrm{SaO}_{2}\right)$ and electrocardiography findings (PR and QT intervals in lead II) were recorded.

To obtain both the systolic and diastolic arterial pressures, a catheter in the metatarsal artery was connected to a pressure transducer from a multi-parameter monitor. Before any measurements were taken, the transducer was zeroed at the level of the right atrium with the dog in lateral recumbency.

Mean values for each variable were obtained from each studied moment and compared using the Tukey test and paired comparison. A comparison between groups took place at MInf and Inf +5 , where the mean values for each variable were analyzed using ANOVA and the following linear model: $\mathrm{Yij}=\mu+\mathrm{Gi}+\varepsilon \mathrm{ij}$. Results were considered statistically significant at $\mathrm{P}<0.01$ and $\mathrm{P}<0.05$.

\section{RESULTS}

As shown in Figure 1, there was no significant difference between mean heart rate values obtained for GI25 and GI38 when compared to the control group at M0, Mflex, MpuDr, MInf and MInf+5.

There were no statistical differences between mean variation of the PR and QT intervals (Figure 2 and 3 ) during infusion and 5 minutes after subarachnoid injection of ioversol at $25^{\circ} \mathrm{C}$ and at $38^{\circ} \mathrm{C}$ when compared with the control group. No cardiac arrhythmias (atrioventricular blocks) were observed during Mflex, MPuDr when compared with M0.

In both GI25 and GI38, there was an elevation in arterial pressure during MInf and MInf+5 moments, though the mean values did not differ statistically from those recorded in the control group (Figure 4 and 5). 


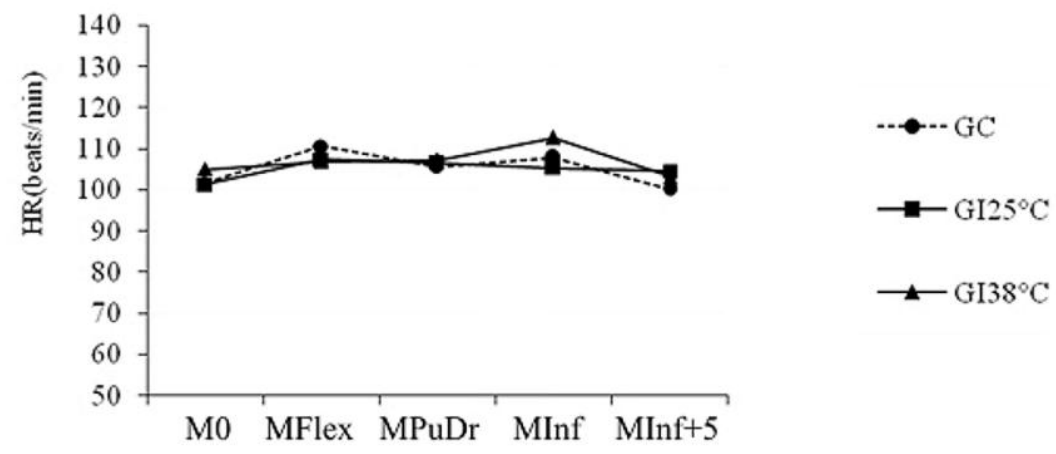

Figure 1. Mean variation in heart rate (HR; beats per minute), in dogs that underwent cervical myelography and subarachnoid infusion of ioversol $320 \mathrm{mgI} / \mathrm{mL}$ at $25^{\circ} \mathrm{C}$ and at $38^{\circ} \mathrm{C}$.

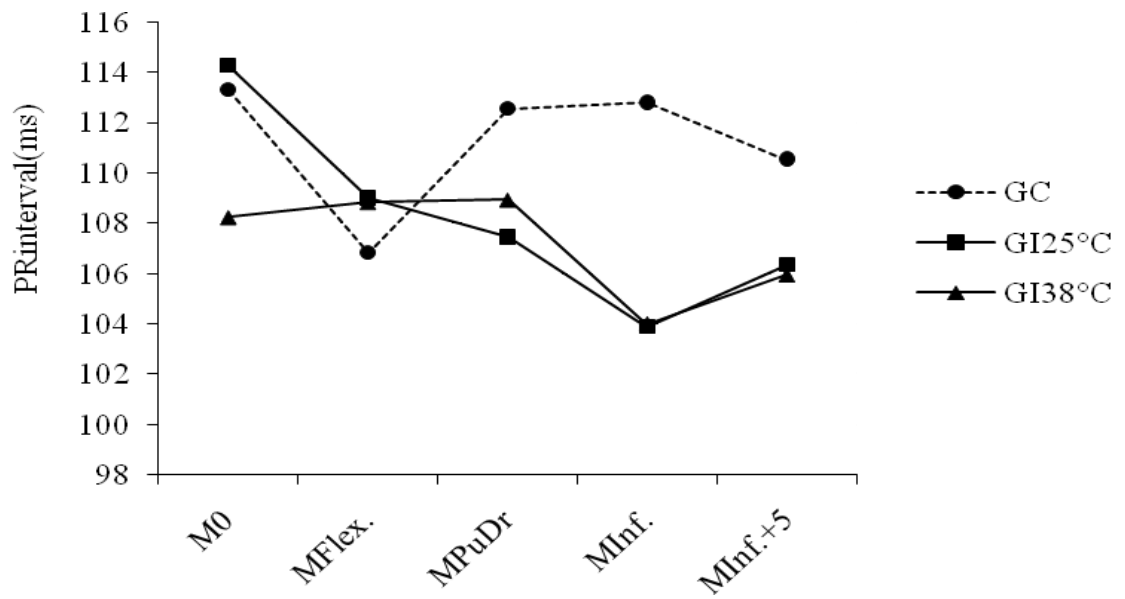

Figure 2. Mean variation of the PR interval (milliseconds), in dogs that underwent cervical myelography and subarachnoid infusion of ioversol $320 \mathrm{mgI} / \mathrm{mL}$ at $25^{\circ} \mathrm{C}$ and at $38^{\circ} \mathrm{C}$.

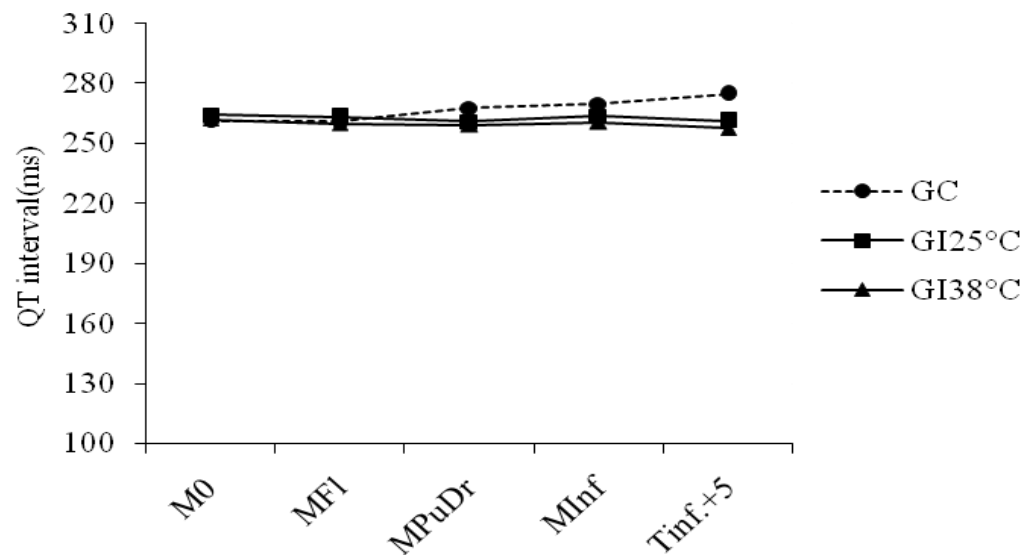

Figure 3. Mean variation of the QT interval (milliseconds), in dogs that underwent cervical myelography and subarachnoid infusion of ioversol $320 \mathrm{mgI} / \mathrm{mL}$ at $25^{\circ} \mathrm{C}$ and at $38^{\circ} \mathrm{C}$. 


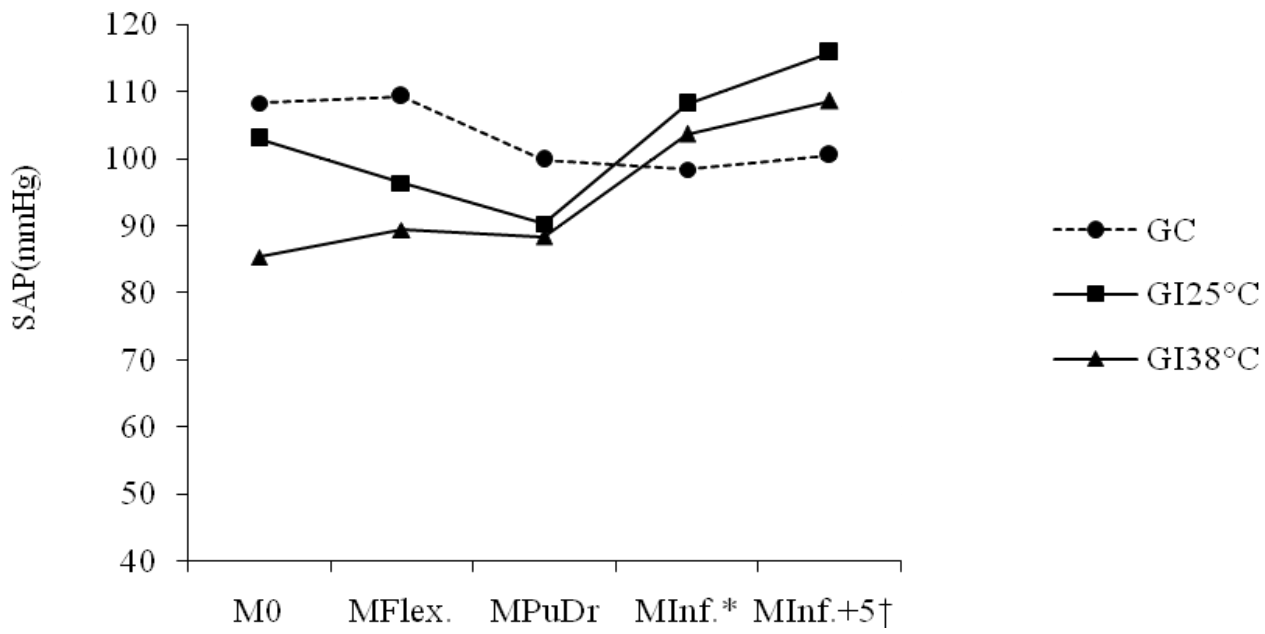

Figure 4. Mean variation in arterial systolic pressure (SAP; millimeter of mercury) in dogs that underwent cervical myelography and subarachnoid infusion of ioversol $320 \mathrm{mgI} / \mathrm{mL}$ at $25^{\circ} \mathrm{C}$ and at $38^{\circ} \mathrm{C}(* \mathrm{P}<0.05 ; \leftrightarrow$ $\mathrm{P}<0.01$ for MPuDr).

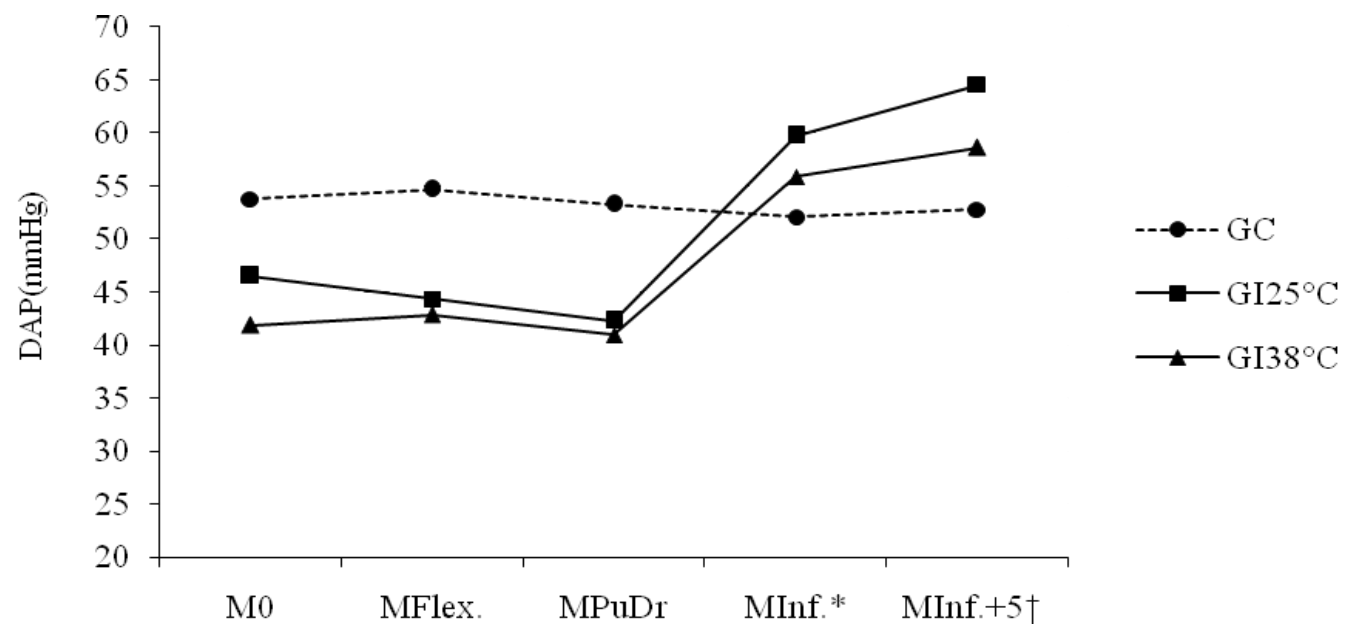

Figure 5. Mean variation in diastolic pressure (DAP; millimeter of mercury) in dogs that underwent cervical myelography and subarachnoid infusion of ioversol $320 \mathrm{mgI} / \mathrm{mL}$ at $25^{\circ} \mathrm{C}$ and at $38^{\circ} \mathrm{C}(* \mathrm{P}<0.05 ; \bullet$ $\mathrm{P}<0.01$ for MPuDr).

The mean saturation values $\left(\mathrm{SaO}_{2}\right)$ had no statistically significant alterations during neck flexion, spinal tap and CSF collection, or between groups injected with ioversol $320 \mathrm{mgI} / \mathrm{mL}$ at $25^{\circ} \mathrm{C}$ and at $38^{\circ} \mathrm{C}$ (Figure 6).

As shown in Figure 7, there was no significant reduction in mean values for respiratory rate, which remained stable during myelography. It was only during the infusion of ioversol and five minutes after its injection that the mean values obtained for the groups injected with ioversol at $25^{\circ} \mathrm{C}$ and heated at $38^{\circ} \mathrm{C}$ showed a significant statistical difference $(\mathrm{P}<0.05)$ when compared with the control group.

Immediately after recovery from anesthesia, neurologic examinations in all dogs showed no abnormalities. 


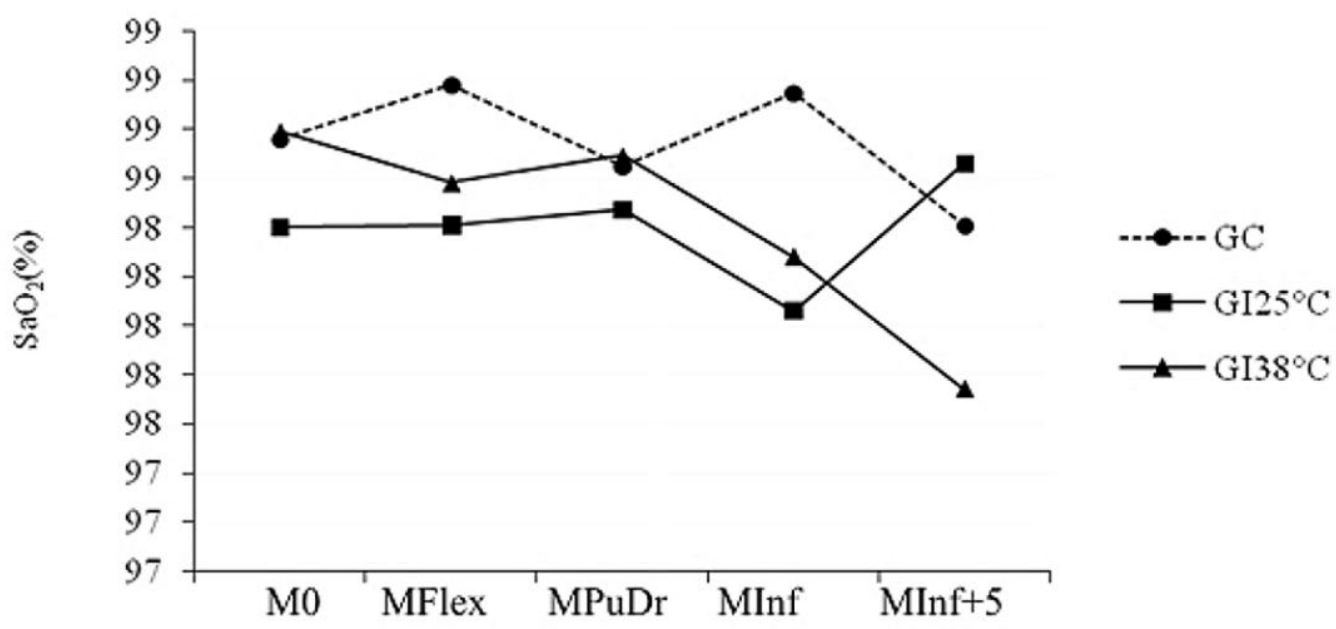

Fig

ure 6. Mean variation of oxyhemoglobin saturation $\left(\mathrm{SaO}_{2}\right)$ in dogs that underwent cervical myelography and subarachnoid infusion of ioversol $320 \mathrm{mgI} / \mathrm{mL}$ at $25^{\circ} \mathrm{C}$ and at $38^{\circ} \mathrm{C}$.

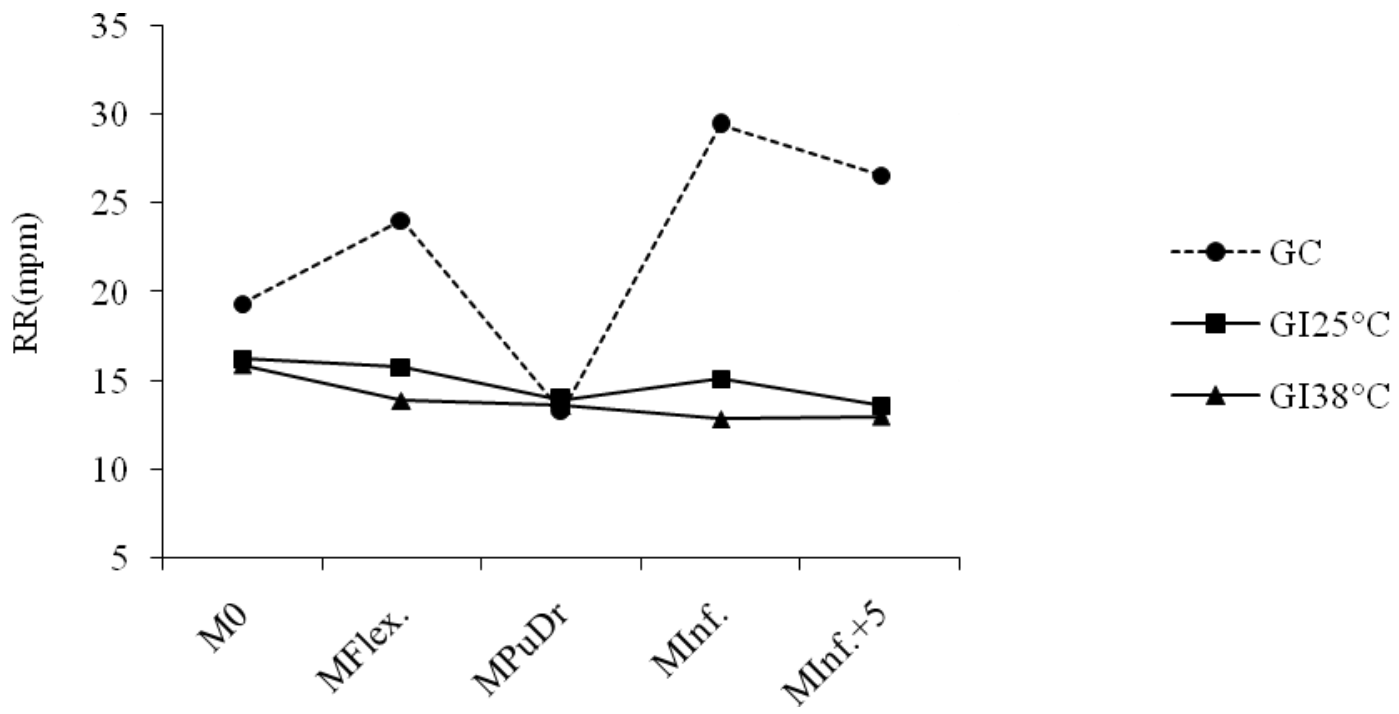

Figure 7. Mean variation for respiratory rate (RR; movements per minute), in dogs that underwent cervical myelography and subarachnoid infusion of ioversol $320 \mathrm{mgI} / \mathrm{mL}$ at $25^{\circ} \mathrm{C}$ and at $38^{\circ} \mathrm{C}$.

\section{DISCUSSION}

To date, there are few publications on the possible cardiovascular and respiratory complications that may arise from myelography using ioversol. Neck flexion, puncture of the cerebellomedullary cistern and subarachnoid infusion of ioversol $(320 \mathrm{mgI} / \mathrm{mL})$ may cause autonomous nervous system stimulation due to the proximity of the medullary region of the caudal brainstem, which controls the cardiovascular and respiratory activity. These alterations were the focus of this investigation, which further reinforced the importance of taking necessary care during the execution of the myelography procedure, so that the possible adverse reactions and long-term side-effects would be minimal (Greenhoot and Mauck, 1972; Evans et al., 1980; Lehmann et al., 1987).

The fact that there was no alteration in heart rate during subarachnoid infusion of ioversol 
$320 \mathrm{mgI} / \mathrm{mL}$ contradicts earlier reports, which observed tachycardia following the infusion of the same contrast medium (Tudury et al., 1997); and bradycardia with the use of iohexol (Lewis and Hosgood, 1992) (cisternal and lumbar injections) and iopamidol (Cox and Jakovljevic, 1986) (cisterna magna). The results obtained in this study were supported by the mean values gathered and compared from continuous monitoring of all dogs that underwent infusion of autologous CSF or ioversol. As such, these authors observed that the heart rate (number of beats per minute) was relatively stable throughout the myelography procedure, not only during subarachnoid infusion of ioversol at $25^{\circ} \mathrm{C}$ or $38^{\circ} \mathrm{C}$

Other researchers mention that cardiac arrhythmias and conduction disturbances, with increase of PR and QT intervals, respectively, were observed in patients undergoing cervical myelography with other contrast mediums, like iopamidol and iohexol (Widmer and Blevins, 1991; Lewis and Hosgood, 1992). These effects were not observed in the present experiment.

This author's choice in using ioversol for cervical myelography, though not indicated by the manufacturers (Mallinckrodt Chemical Ltd., Chesterfield, UK - Optiray 320), was supported by its use in Canada (Health Canada, 2011). The results obtained within these research parameters (ioversol $320 \mathrm{mgI} / \mathrm{mL}$, subarachnoidally, at $25^{\circ} \mathrm{C}$ and $38^{\circ} \mathrm{C}$ ) were encouraging due to the absence of cardiac arrhythmias.

Some researchers have registered a fall in arterial pressure in $\operatorname{dogs}$ and humans when ioversol is administered intravascularly (Benamor et al., 1989; Hirshfeld et al., 1989; Ralston et al., 1989). The present results differed in that we found that ioversol $320 \mathrm{mgI} / \mathrm{mL}$ significantly increased arterial systolic (PAS) and diastolic pressures (DAP) to values close to initial values. At the time of infusion, both PAS and DAP were below base values (M0), which we attributed to the effects of general anesthesia with isoflurane. It is unclear whether this elevation in arterial pressure resulted from the volume of ioversol injected into the cerebellomedullary cistern or because of the proximity of the medullary region of the caudal brainstem, which would stimulate the sympathetic nerve tracts, causing a vasopressor response and thus increasing the systemic arterial pressure during and five minutes after infusion (Greenhoot and Mauck, 1972; Evans et al., 1980). Based on this information, it is necessary to check arterial pressure before subarachnoid infusion in patients who have sustained trauma to the spinal cord, especially when there is involvement of the lumbar segments, which would require the use of a higher volume of contrast medium.

Pulse oxymetry showed no change in $\mathrm{SaO} 2$ throughout the experiment, probably because there was no significant reduction in $R R$ and proper oxygenation was ensured (Nunes, 2002).

There was no significant change in RR between groups during positioning (neck flexion) and puncture of the cerebellomedullary cistern, which contradicts a previous report (Clark, 1986) which mentions transient respiratory arrest in patients during positioning for myelography. In the control group, the elevation in respiratory rate was attributed to the reinfusion of CSF into the subarachnoid space, which would have brought the circulating volume back to normal and restored the respiratory pattern. Although the dogs that received an infusion of ioversol had respiratory rates statistically lower than the control group, the values remained within normal parameters (10 - 30 movements/min). There were no registered occurrences of apnea (Tudury et al., 1997) or respiratory arrest (Clark, 1986; Lehmann et al., 1987) during subarachnoid infusion, which supports the claim that ioversol is safe regarding its effects on the respiratory function.

The use of isoflurane for maintenance of anesthesia did not influence the electrocardiography findings during cervical myelography and infusion of ioversol (320mgI/mL). No cardiac arrhythmias were observed, but it is recommended that the injection of ioversol be monitored by ECG since there is a risk of autonomic stimulation, which may cause cardiac arrhythmias and a fall in arterial pressure (Nunes, 2002; Paiva et al., 2002).

Though not included within the objectives of this research, it was possible to observe there were no neurological alterations during recovery from anesthesia in the dogs that underwent myelography with the use of ioversol 320 
$\mathrm{mgI} / \mathrm{mL}$. This is in agreement with other findings (Ralston et al., 1989; Tudury et al., 1997), and supports that ioversol has a low epileptogenic activity. It also reinforces its indication for myelography.

\section{CONCLUSION}

The steps involved in performing a cervical myelography, such as neck flexion, puncture of the cerebellomedullary cistern, drainage of CSF, and the use of ioversol $320 \mathrm{mgI} / \mathrm{mL}$ at $0.3 \mathrm{~mL} / \mathrm{kg}$ $\left(25^{\circ} \mathrm{C}\right.$ and $\left.38^{\circ} \mathrm{C}\right)$ show no detrimental effects regarding heart or respiratory rate and oxyhemoglobin saturation. Although it did elevate arterial pressure, no cardiac arrhythmias or impulse conduction abnormalities, changes in respiratory rate or oxyhemoglobin saturation were observed. These observations show that ioversol $(320 \mathrm{mgI} / \mathrm{mL})$ at $0.3 \mathrm{~mL} / \mathrm{kg}\left(25^{\circ} \mathrm{C}\right.$ or $38^{\circ} \mathrm{C}$ ) had minimal effects when administered subarachnoidally for cervical myelography in dogs.

\section{REFERENCES}

BENAMOR, M.; ATEN, E.M.; McELVANY, K.D. et al. Ioversol clinical safety summary. Invest. Radiol., v.24, p.67-72, 1989.

CLARK, D.M. An analysis of intraoperative and early postoperative mortality associated with cervical spinal decompressive surgery in the dog. J. Am. Anim. Hosp. Assoc., v.22, p.739-744, 1986.

COX, F.H.; JAKOVLJEVIC, S. The use of iopamidol for myelography in dogs: a study of twenty-seven cases. Vet. Clin. N. Am.: Small Anim. Pract., v.27, p.159-165, 1986.

DOUCET, D.; IDÉE, J.M. Profil pharmacotoxicologique d'un LOCM non ionique à haute hidrophilie: ioversol. Ann. Radiol., v.35, p.267$272,1992$.

HEALTH CANADA. Drug Product Database (DPD). Canada: Health Canada. Disponível em: <http://www.hc-sc.gc.ca/hpb/drugs-

dpd/product/p43427.html . Acessado em: 08/ago./2011.

EVANS, D.E.; KOBINE, A.I.; RIZZOLI, H.V. Cardiac arrhythmias accompanying acute compression of the spinal cord. J. Neurosurg., v.52, p.52-59, 1980.

FRIGENI, V.; SAMUELLI, G.; MIRAGOLI, L. Effect of iomeprol on rat hippocampal slice synaptic transmission: comparison with other x-ray contrast agents. Invest. Radiol., v.37, p.222-231, 2002.
GELMERS, H.J. Adverse side effects of metrizamide in myelography. Neuroradiology, v.18, p.119-123, 1979.

GREENHOOT, J.H.; MAUCK, H.P. The effect of cervical cord injury on cardiac rhythm and conduction. Am. Heart J., v.83, p.659-662, 1972.

HIRSHFELD Jr., J.W.; WIELAND J.; DAVIS, C.A. et al. Hemodynamic and electrocardiographic effects of ioversol during cardiac angiography: Comparison with iopamidol and diatrizoate. Invest. Radiol., v.24, p.138-144, 1989.

JACOBSEN, P.B. High performance liquid chromatography with multiwavelength detection: a technique for identification of iodinated $\mathrm{x}$-ray contrast agents in human body fluid and brain tissue. Am. J. Neuroradiol., v.13, p.1521-1525, 1992.

LA NOCE, A.; LORENZON P.; PUGLIESE F. et al. Brain penetration of intrathecal iomeprol in dogs. Acta Radiol., v.37, p.578-581, 1996.

LEHMANN, K.G.; LANE, J.G.; PIEPMEIER, J.M. et al. Cardiovascular abnormalities accompanying acute spinal cord injury in human: incidence, time course and severity. J. Am. Coll. Cardiol., v.10, p.46-52, 1987.

LEWIS, D.D.; HOSGOOD, G. Complications associated with the use of iohexol for myelography of the cervical vertebral column in dogs: 66 cases (19881990). J. Am. Vet. Med. Assoc., v.200, p.1381-1384, 1992.

McCLENNAN, B.J.; BETTMANN, M.J. Conclusion: Utility and safety of ioversol. Invest. Radiol., v.24, p.73-76, 1989 .

NUNES, N. Monitoramento da anestesia In: FANTONI, D.T; CORTOPASSI, S.R. Anestesia em cães e gatos. São Paulo: ROCA, 2002. p.64-81.

PAIVA, J.P.; MARSICO FILHO, F.; RAMADINHA, R.H.R. et al. Alterações eletrocardiográficas durante a intubação endotraqueal em cães induzidos anestesiologicamente com tiopental sódico, propofol ou etomidato, com e sem pré-oxigenação. Rev. Bras. Cienc. Vet., v.9, p.325-327, 2002.

RALSTON, W.H.; ROBBINS, M.S.; COVENEY, J.R. et al. Acute and subacute toxicity studies of ioversol in experimental animals. Invest. Radiol., v.24, p.2-9, 1989.

ROBERTS, R.E.; SELCER, B.A. Myelography and epidurography. Vet. Clin. N. Am.: Small Anim. Pract., v.23, p.307-328, 1993.

TUDURY, E.A.; ARIAS, M.V.B.; CAMARGO, P.L. et al. Meio de contraste ioversol em neuroradiologia canina. Cienc. Rural, v.27, p.1-5, 1997. 
Melo e Silva et al.

WHEELER, S.J.; SHARP, N.J.H. Diagnóstico $e$ tratamento cirúrgico das afecções espinhais do cão e gato. São Paulo: MANOLE, 1999. p.63-64.

WIBLE, J.H.; BARCO, S.J.; SCHERRER, D.E. Neurotoxicity of non-ionic X-ray contrast media after intracisternal administration in rats. Eur. J. Radiol., v.19, p.206-211, 1995.
WIDMER, W.R.; BLEVINS, W.E. Veterinary myelography: a review of contrast media, adverse effects and technique. J. Am. Anim. Hosp. Assoc., v.27, p.163-177, 1991. 